\title{
Perfeksionisme pada Penari: Adaptif atau Maladaptif?
}

\section{Is Perfectionism among Dancers Adaptive or Maladaptive?}

\author{
Talitha Noveasara Dayo ${ }^{1}$, Syarifah Faradina ${ }^{2}$ \\ 1,2Program Studi Psikologi, Fakultas Kedokteran, Universitas Syiah Kuala \\ Submitted 19 December 2019 Accepted 27 April $2020 \quad$ Published 23 May 2020
}

\begin{abstract}
Dance is an artwork performed by dancers that master the technical art of dance which perform either individual or groups. Dancers receive subjective evaluation such as criticism and strive to increase performance quality that leads to perfectionism tendency. Perfectionism is defined as setting a high standard on performance or task and categorized into adaptive (conscientious perfectionism) which motivates individual to be composed and organized, and also maladaptive (self-evaluative perfectionism) which causes individual to criticize oneself excessively. This study aimed to determine the level perfectionism of dancers in Aceh with 343 dancers consisted of 219 women and 124 men with age range 19-39 years $(M=21.38)$ and selected with purposive sampling technique. Data collection used Perfectionism Inventory $(\alpha)=0.917$. This research employed quantitative descriptive method. The result of descriptive and crosstab showed that $290(84.5 \%)$ dancers in Aceh had a high level of perfectionism, especially in the categorization of traditional dance types, female dancers, and early adult dancers. The results also showed that self-evaluative perfectionism of dancers in Aceh was at a high level, meanwhile conscientious perfectionism was at a low level.
\end{abstract}

Keywords: conscientious perfectionism; dancers; perfectionism; self-evaluative perfectionism

Abstrak. Tarian merupakan salah satu hasil karya seni yang dilakukan oleh penari yang menguasai teknik-teknik tari tertentu yang dilakukan, baik secara individu maupun kelompok. Penari mendapatkan penilaian subjektif berupa kritikan dan dituntut untuk meningkatkan kualitas penampilan yang menimbulkan kecenderungan perfeksionisme. Perfeksionisme adalah penetapan standar tinggi pada suatu kinerja atau penampilan yang bersifat adaptif (conscientious perfectionism) yang mendorong individu menjadi teratur dan rapi, dan bersifat maladaptif (selfevaluative perfectionism) yang menjadikan individu menilai diri secara negatif dan berlebihan. Penelitian ini bertujuan untuk mengetahui tingkat perfeksionisme pada penari di Aceh terhadap 343 penari yang terdiri dari 219 perempuan dan 124 laki-laki dengan rentang usia 19-39 tahun $(M=21,38)$ yang dipilih dengan menggunakan purposive sampling. Pengumpulan data penelitian menggunakan Perfectionism Inventory dengan $(\alpha)=0,917$. Penelitian ini menggunakan metode kuantitatif deskriptif. Hasil analisis deskriptif dan crosstab menunjukkan bahwa perfeksionisme pada 290 (84,5\%) penari Aceh berada pada tingkat tinggi, terutama pada kategorisasi jenis tari tradisional, penari perempuan, dan penari berusia dewasa awal. Hasil analisis juga menunjukkan bahwa self-evaluative perfectionism berada pada kategori tinggi, sedangkan conscientious perfectionism berada pada kategori rendah.

Kata kunci: conscientious perfectionism; penari; perfeksionisme; self-evaluative perfectionism

${ }^{1}$ Korespondensi mengenai artikel ini dapat dilakukan melalui talithanoveasara@gmail.com 2atau sy.faradina@unsyiah.ac.id 
Tari adalah proses untuk menyampaikan suatu gerakan dan bentuk kepada para penonton (Jackson, 2005). Tari merupakan cerminan budaya berupa identitas pada sekelompok masyarakat dan sekaligus sebagai suatu pekerjaan yang menghasilkan suatu karya seni (Restela \& Narawati, 2017). Tarian Aceh ditampilkan secara berkelompok yang menunjukkan karakteristik masyarakat Aceh yang menjaga nilai solidaritas, kekompakan, dan kebersamaan dalam kelompok. Tarian Aceh memiliki ciri khas yang berasal dari karakteristik masyarakat Aceh berupa struktur adat, tingkah laku, dan pola pikir (Restela \& Narawati, 2017). Tarian Aceh umumnya ditampilkan dalam berbagai kegiatan seperti upacara adat pernikahan, penyambutan tamu, pertunjukan pembuka pada acara peresmian, maupun sebagai pertunjukan umumnya sebagai pementasan seni budaya (Agustina, 2018).

Penari merupakan individu yang melakukan aktivitas tari dengan melibatkan perpaduan antara aspek fisik dan aspek kognitif (Bläsing \& Schack, 2012; Chua, 2014; Eusanio et al., 2014; Koutedakis \& Jamurtas, 2004). Penari memerlukan proses kognitif untuk menyelaraskan antara gerakan dengan waktu, musik, dan koordinasi dengan penari lainnya (Bläsing \& Schack, 2012; Chua, 2014). Keterampilan lain yang dibutuhkan oleh penari adalah keterampilan seni dan ketangkasan fisik sehingga penari disebut "performing athlete" (Koutedakis \& Jamurtas, 2004). Keterlibatan kedua keterampilan tersebut menimbulkan suatu keadaan agar peran sebagai atlet sekaligus penampil seni harus dilakukan secara seimbang, yaitu kesuksesan penampilan secara fisik yang sama baiknya dengan pencapaian keindahan yang ideal (Eusanio et al., 2014).

Selain dinamika peran pada penari, terdapat juga isu psikologi pada penari. Eusanio et al. (2014) menjelaskan bahwa terdapat tuntutan pada penari untuk meraih prestasi, keunggulan, dan kesempurnaan dalam penampilan. Selain itu, penilaian pada suatu karya seni dapat berasal dari lingkungan sosial penari dan orang terdekat, baik dari pelatih tari maupun sesama anggota tim (Conroy et al., 2001). Salah satu tari di Aceh, contohnya tari Didong Gayo, dinilai oleh para juri yang umumnya merupakan mantan "ceh" (penyair) atau orang yang memahami adat kesenian Didong (Setyantoro, 2014). Penilaian yang bukan berdasarkan skor, menjadikan penilaian pada suatu karya seni bersifat lebih subjektif (Conroy et al., 2001). Meskipun terdapat penilaian yang bersifat subjektif, penari harus menerima berbagai kritikan dan terus berusaha untuk meningkatkan kualitas penampilan (Yatabe et al., 2014).

Pada umumnya penari adalah perfeksionis (Rasminsky, 2009). Sifat perfeksionisme kemudian menjadi salah satu hal yang memengaruhi seorang penari (Eusanio et al., 2014; Stoeber \& Stoeber, 2009). Selain terdapat perfeksionisme bersifat negatif seperti mengevaluasi diri secara berlebihan, terdapat juga perfeksionisme bersifat positif seperti kemampuan memotivasi orang lain (Hewitt \& Flett, 1991). Pada penari, timbulnya kecemasan yang terus-menerus untuk mencapai standar-standar yang tidak mungkin tercapai yang menjadikan perfeksionisme maladaptif atau neurotic. Lebih lanjut, perfeksionisme juga bermakna 
positif ketika perfeksionisme dapat meningkatkan kualitas penari seperti kemampuan menerima suatu kegagalan maupun ketika menjadikan penari lebih teratur dan rapi (Rasminsky, 2009).

Perfeksionisme awal mulanya dikenal sebagai suatu konstruk dengan dimensi tunggal, yaitu hanya berdasarkan sudut pandang kognitif (Burns, 1980). Perfeksionisme muncul ketika individu menetapkan standar yang tinggi, namun tidak mungkin untuk mencapai standar tersebut, sehingga dapat merugikan diri individu (Burns, 1980). Konsep perfeksionisme juga dikenal sebagai konstruk yang bersifat multidimensional, yaitu konstruk yang menjelaskan berdasarkan sudut pandang pribadi dan sosial (Frost et al., 1990; Hewitt \& Flett, 1991). Perfeksionisme memiliki hubungan dengan psikopatologi, namun perfeksionisme juga memiliki aspek yang positif seperti menjadikan individu teratur dalam perencanaan strategi kerja (Frost et al., 1990). Perfeksionisme merupakan suatu perilaku dengan karakteristik memiliki motivasi untuk menjadi sempurna, dan menetapkan standar yang tinggi untuk diri sendiri (self-oriented perfectionism), menetapkan standar yang tinggi untuk orang lain (other-oriented perfectionism), dan suatu keyakinan diri atau persepsi bahwa individu lain memberikan tekanan akan kesempurnaan dan mengevaluasi secara ketat (socially-prescribed perfectionism) (Hewitt \& Flett, 1991). Lebih lanjut, perfeksionisme juga merupakan suatu kecenderungan dalam diri individu yang mengarahkan pada perfeksionisme yang terbagi menjadi conscientious perfectionism dan self-evaluative perfectionism (Hill et al., 2004).

\section{Metode}

Penelitian ini melibatkan variabel perfeksionisme dengan metode kuantitatif deskriptif. Metode analisis data penelitian yang digunakan adalah analisis deskriptif dan crosstab untuk melihat persebaran dan jumlah data demografi serta tingkat perfeksionisme pada seluruh partisipan penelitian, dan menggambarkan frekuensi atau proporsi kejadian yang terdapat pada variabel terikat terhadap seluruh kelompok.

$$
\text { Partisipan penelitian dipilih }
$$
menggunakan teknik purposive sampling dengan jumlah 343 penari. Kriteria partisipan penelitian yaitu penari berdomisili di seluruh kabupaten/ kota di Provinsi Aceh, keanggotaan dari sanggar tari di Aceh, pernah mengikuti salah satu ajang tari, penari berjenis kelamin laki-laki dan perempuan, dan berusia lebih dari 19 tahun.

Metode pengumpulan data dalam penelitian ini menggunakan Perfectionism Inventory (PI). Perfectionism Inventory (Hill et al., 2004) terdiri dari dimensi self-evaluative perfectionism (keadaan mengevaluasi diri) yang terbagi menjadi concerned over mistakes, need for approval, perceived parental pressure, dan rumination. Dimensi lainnya, conscientious perfectionism (rasa tanggung jawab terhadap suatu hal) terbagi menjadi high standards for others, organization, planfulness, dan striving for excellence. Skala PI terdiri dari 59 aitem yang terdiri dari 5 pilihan jawaban yaitu sangat tidak setuju diberi nilai 1 hingga sangat setuju diberi nilai 5 . 
PI terdiri dari delapan sub dimensi yaitu concerned over mistakes, high standards for others, need for approval, organization, perceived parental pressure, planfulness, rumination, dan striving for excellence. Delapan subdimensi Perfectionism Inventory merupakan gabungan antara dimensi perfeksionisme yang diungkapkan oleh (Hewitt \& Flett, 1991) dengan (Frost et al., 1990). Nilai koefisien alpha Cronbach dari skala Perfectionism Inventory (Hill et al., 2004) yaitu 0,83. Perolehan nilai reliabilitas alpha Cronbach dari skala Perfectionism Inventory (PI) pada saat uji coba (try out) dan penelitian secara berturut-turut yaitu 0,917 dan 0,898 .

\section{Hasil}

\section{Data deskriptif}

Penelitian ini melibatkan 343 partisipan penelitian berusia 19 hingga 39 tahun yang berdomisili di Provinsi Aceh. Partisipan penelitian terdiri dari $124(36,2 \%)$ berjenis kelamin laki-laki dan 219 (63,8\%) berjenis kelamin perempuan. Ditinjau berdasarkan usia, jumlah tertinggi berada pada rentang usia 20-24 tahun yang berjumlah 197 (57,4\%), sedangkan rentang usia paling rendah yaitu usia 25-39 tahun berjumlah 36 $(10,5 \%)$. Berdasarkan jenis tari yang dikuasai, tingkat tertinggi berada pada penari tradisional berjumlah 236 (69\%), sedangkan penari tradisional dan kreasi berada pada tingkat terendah berjumlah 107 (31\%).

\section{Uji asumsi}

Penentuan uji asumsi pada penelitian ini didapatkan setelah data diolah, sehingga uji asumsi dilakukan sejalan dengan pengujian
Crosstab. Adapun asumsi penelitian ini adalah apabila bentuk tabel kontingensi berukuran 2x2, maka seluruh sel harus memiliki frekuensi harapan (expected frequency) lebih dari 5. Apabila bentuk tabel kontingensi berukuran lebih dari 2x2, maka jumlah sel dengan frekuensi harapan (expected frequency) yang berjumlah kurang dari 5, tidak boleh lebih dari 20\% (Pallant, 2011).

Tabel yang diujikan dalam penelitian terdiri dari 9 tabel dengan ukuran tabel 2x2, dan dinyatakan memiliki jumlah cell dengan nilai frekuensi harapan di atas 5 . Pada 3 tabel yang berukuran 2x3 memiliki satu cell dengan frekuensi harapan kurang dari 5, tetapi frekuensi harapan yang kurang dari 5 tidak melebihi 20\%. Oleh karena itu, 12 tabel yang diujikan dalam penelitian ini tidak melanggar uji asumsi dan dapat melanjutkan pada tahap analisis data.

\section{Uji statistik}

Uji statistik dilakukan dengan menggunakan analisis crosstab. Hasil analisis crosstab terdapat pada Tabel 1.

Hasil analisis data menunjukkan bahwa berdasarkan jenis tari, kategori perfeksionisme tinggi berada pada 201 penari tradisional, sedangkan penari tradisional dan kreasi memiliki jumlah yang lebih rendah yaitu 89 penari. Berdasarkan jenis kelamin, kategori perfeksionisme tinggi berada 186 penari berjenis kelamin perempuan. Hasil yang berbeda dengan penari berjenis kelamin laki-laki yang berada pada jumlah yang lebih rendah yaitu 104 penari. Perfeksionisme yang ditinjau berdasarkan usia, sejumlah 200 penari berusia dewasa awal berada pada 
Tabel 1.

Hasil Analisis Crosstab Perfeksionisme dengan Data Demografi

\begin{tabular}{clcc}
\hline Deskripsi Demografi & \multicolumn{1}{c}{ Perfeksionisme } & Jumlah & Persentase (\%) \\
\hline Jenis Tari & Penari Tradisional & 35 & 14 \\
& Rendah & 201 & 86 \\
& Tinggi & & \\
& Penari Tradisional dan Kreasi & 18 & 16 \\
& Rendah & 89 & 84 \\
& Tinggi & & \\
Jenis Kelamin & Laki-laki & 20 & 17 \\
& Rendah & 104 & 83 \\
& Tinggi & & \\
& Perempuan & 33 & 15 \\
& Rendah & 35 \\
& Tinggi & 186 & \\
& Remaja Akhir & & \\
& Rendah & 20 & \\
& Tinggi & 90 & 82 \\
& Dewasa Awal & & \\
& Rendah & 33 & \\
& Tinggi & 200 & \\
\hline
\end{tabular}

kategori perfeksionisme tinggi. Lebih lanjut, usia remaja akhir berada pada jumlah yang lebih rendah yaitu 90 penari.

\section{Kategorisasi Hasil Penelitian}

Kategorisasi perfeksionisme dan dimensi perfeksionisme pada penari di Aceh dapat dilihat pada Tabel 2.

Berdasarkan Tabel 2, diketahui bahwa $290(84,5 \%)$ penari berada pada kategori perfeksionisme tinggi, dan 53 (15,5\%) penari berada pada kategori perfeksionisme rendah. Kategorisasi conscientious perfectionism menunjukkan bahwa 282 $(82,2 \%)$ penari berada pada kategori tinggi, dan 61 (17,8\%) penari berada pada kategori rendah. Pada kategorisasi self-evaluative perfectionism, $290(84,5 \%)$ penari berada pada kategori tinggi, dan 53 (15,5\%) penari berada pada kategori rendah.

Hasil akhir penelitian ini menunjukkan bahwa 290 (84,5\%) penari di Aceh memiliki tingkat perfeksionisme tinggi dari jumlah total 343 partisipan penelitian. Perfeksionisme pada penari di Aceh tergolong dalam self-evaluative perfectionism (maladaptif) dengan persentase $84,5 \%$. Lebih lanjut, analisis data sosiodemografi partisipan penelitian menunjukkan bahwa penari di Aceh memiliki perfeksionisme tinggi pada kategori penari tradisional (86\%), penari perempuan $(85 \%)$, dan penari berusia dewasa awal $(86 \%)$. 
Tabel 2.

Kategorisasi Perfeksionisme dan Dimensi Perfeksionisme

\begin{tabular}{lcccc}
\hline \multicolumn{1}{c}{ Skala } & $\begin{array}{c}\text { Rumus } \\
\text { Kategorisasi }\end{array}$ & Kategorisasi & Jumlah & $\begin{array}{c}\text { Persentase } \\
\text { (\%) }\end{array}$ \\
\hline Perfeksionisme & $\mathrm{X}>31,1$ & Tinggi & 290 & 84,5 \\
& $\mathrm{X}<24,76$ & Rendah & 53 & 15,5 \\
Conscientious & $\mathrm{X}>16,53$ & Tinggi & 282 & 82,2 \\
Perfectionism & $\mathrm{X}<13,15$ & Rendah & 61 & 17,8 \\
Self-Evaluative & $\mathrm{X}>15,08$ & Tinggi & 290 & 84,5 \\
Perfectionism & $\mathrm{X}<11,1$ & Rendah & 53 & 15,5 \\
\hline
\end{tabular}

\section{Diskusi}

Penelitian ini bertujuan untuk mengetahui tingkat perfeksionisme pada penari di Aceh. Hasil penelitian menunjukkan bahwa penari di Aceh memiliki tingkat perfeksionisme yang tinggi. Hasil penelitian ini didukung oleh penelitian Nordin-Bates et al. (2011) bahwa penari memiliki kecenderungan perfeksionisme tinggi. Penari memiliki kecenderungan perfeksionisme tinggi dikarenakan terdapat skor self-evaluative perfectionism (perfeksionisme yang mengevaluasi diri) yang tinggi dan memiliki hubungan dengan tingkat kepercayaan diri yang rendah, tuntutan untuk meraih keunggulan, dan intensitas kecemasan yang tinggi. Penelitian Goodwin et al. (2014) juga menyatakan bahwa penari memiliki perfeksionisme yang tinggi, terutama pada self-evaluative perfectionism. Hasil penelitian Gittens (2012) juga menyebutkan bahwa penari memiliki tingkat perfeksionisme yang tinggi. Hal tersebut dikarenakan penari mengalami tingkat kecemasan yang tinggi sehingga menyebabkan meningkatnya perfeksionisme, terutama yang maladaptif. Penelitian tersebut lebih lanjut menjelaskan bahwa penari lebih tinggi pada tingkat perfeksionisme maladaptif dikarenakan penari tidak dapat menerima kesalahan yang terjadi di dalam suatu penampilan (Gittens, 2012).

Perfeksionisme pada penari berada pada kategori tinggi dikarenakan berada pada lingkungan yang kompetitif, menuntut kesempurnaan, dan standar yang tinggi. Lingkungan penari yang kompetitif menjadikan penari mendapat tekanan dari pelatih untuk berlatih secara maksimal agar mencapai hasil yang sempurna (Goodwin et al., 2014; Thomas et al., 2005). Gittens (2012) menjelaskan bahwa penari juga menetapkan standar yang tinggi terhadap diri sendiri, hal ini dikarenakan adanya keinginan dalam diri penari untuk mendapatkan suatu prestasi, maka terdapat dorongan dalam diri untuk terus meningkatkan prestasi tersebut. Penari menetapkan standar-standar yang tinggi untuk membuktikan bahwa penari tersebut layak untuk mendapatkan posisi atau prestasi yang telah diraih. Penetapan standar yang tinggi juga dilakukan untuk menghindari kritikan dari orang lain (Gittens, 2012). Penetapan standar kinerja yang tinggi dan dorongan untuk menjadi unggul merupakan komponen utama dari 
perfeksionisme (Gittens, 2012; Krasnow et al., 1999).

Perfeksionisme jika ditinjau berdasarkan dimensi, didapatkan hasil analisa bahwa self-evaluative perfectionism pada penari di Aceh berada pada kategori tinggi $(84.5 \%)$. Dimensi yang dominan berupa self-evaluative perfectionism, bermakna bahwa partisipan penelitian memiliki kecenderungan unhealthy perfectionism (Stoeber \& Otto, 2006). Unhealthy perfectionist yaitu individu dengan keinginan atau dorongan untuk menjadi lebih baik, namun tidak dapat menerima keterbatasan maupun ketidaksempurnaan yang juga terjadi di dalam prosesnya (Chan, 2010). Individu dengan perfeksionisme maladaptif umumnya menetapkan standar yang tinggi yang tidak mungkin dicapai dan selalu menghindari melakukan kesalahan (Schuler, 2000). Penari yang tidak dapat menerima kesalahan atau sangat tidak puas dengan suatu penampilan yang tidak sempurna ialah penari dengan kecenderungan perfeksionisme yang maladaptif (Gittens, 2012). Hasil penelitian Nordin-Bates (2020) juga menunjukkan bahwa penari yang mendapatkan kritikan maupun hukuman dapat menimbulkan rasa khawatir dan melakukan evaluasi negatif terhadap diri sehingga menimbulkan self-evaluative perfectionism.

Penari di Aceh yang tampil secara berkelompok dapat menjadi salah satu faktor tingkat self-evaluative perfectionism yang tinggi. Dinamika kelompok yang negatif seperti komunikasi atau hubungan yang buruk antara pelatih dengan penari, maupun komunikasi atau hubungan yang buruk antara penari dengan sesama rekan penari juga dapat menimbulkan perfeksionisme yang bersifat maladaptif (Nordin-Bates, 2020). Lebih lanjut, NordinBates (2020) menjelaskan bahwa tarian kelompok memerlukan kolaborasi yang baik, sehingga apabila terdapat individu yang mendominasi di dalam kelompok dapat menimbulkan permasalahan. Individu yang mendominasi tersebut dapat menghalangi individu lain untuk berkembang dan dapat menimbulkan selfcriticism bahwa diri sendiri tidak cukup baik. Hasil penelitian Goodwin et al. (2014) juga mendukung bahwa penetapan standar yang tinggi atau dorongan untuk menjadi unggul tidak menjadi penyebab utama, selama lingkungan tari tidak terus-menerus meningkatkan evaluasi negatif yang menimbulkan kritikan terhadap diri penari (self-criticism).

Lebih lanjut, penari berjenis kelamin perempuan termasuk dalam kategori perfeksionisme tinggi. Hasil penelitian ini didukung oleh penelitian Nordin-Bates et al. (2011) bahwa penari perempuan memiliki kecenderungan perfeksionis yang lebih tinggi. Schuler (2000) juga menjelaskan bahwa perfeksionisme lebih tinggi pada jenis kelamin wanita dikarenakan wanita lebih memerhatikan kerapian dalam berpenampilan maupun gaya berpakaian. Nordin-Bates et al. (2011) juga menyatakan bahwa jumlah penari laki-laki umumnya lebih sedikit, sehingga penari laki-laki tidak terlalu berkompetisi untuk meraih prestasi di bidang pendidikan maupun pekerjaan. Penari wanita yang lebih berkompetisi untuk meraih prestasi yang kemudian menimbulkan tingkat perfeksionisme yang lebih tinggi (Nordin-Bates et al., 2011). 
Hasil analisis menunjukkan bahwa sejumlah 201 penari tradisional berada pada kategori perfeksionisme tinggi. Hal tersebut dikarenakan tarian tradisional lebih berfokus pada kesempurnaan penampilan daripada sensasi atau emosi yang dirasakan dari seni yang ditampilkan (Jackson, 2005). Tarian tradisional juga bersifat tidak fleksibel, yaitu penari harus patuh dan tunduk terhadap perintah dan aturan yang diberikan oleh pelatih (Morris, 2003). Penelitian Nordin-Bates (2020) juga menunjukkan hasil bahwa tarian klasik atau tradisional lebih cenderung menimbulkan perfeksionisme dibandingkan tarian kontemporer. Hal tersebut dikarenakan tarian klasik lebih berfokus pada aturan teknis yang spesifik seperti yang diajarkan oleh pelatih maupun seperti aturan umumnya. Aturan teknis yang terdapat pada tarian tradisional menyebabkan penari tidak dapat mengembangkan kreativitas pada sebuah tarian (Morris, 2003).

Lebih lanjut, penari kontemporer memiliki perfeksionisme yang lebih rendah dikarenakan melibatkan kreativitas pada tarian. Kreativitas pada tarian dibentuk melalui metode latihan yang beragam, misalnya pelatih melibatkan penari dalam mengembangkan suatu tarian (Morris, 2003). Kreativitas pada suatu tarian dapat membantu mengurangi rasa khawatir maupun ketakutan akan kegagalan sehingga dapat mengurangi perfeksionisme (Nordin-Bates, 2020).

Partisipan penelitian dengan usia 19 tahun dikategorikan sebagai remaja akhir dan usia 20-39 tahun dikategorikan sebagai dewasa awal (Papalia et al., 2011). Hasil analisis menunjukkan bahwa sejumlah 200 penari berusia dewasa awal termasuk dalam kategori perfeksionisme tinggi. Goodwin et al., (2014) menyebutkan bahwa kecenderungan perfeksionisme merupakan bagian dari perkembangan manusia. Perfeksionisme semakin meningkat seiring pertambahan usia, dikarenakan tekanan dan kompetisi dalam kehidupan sehari-hari yang juga semakin meningkat (NordinBates et al., 2011). Pada tahapan dewasa awal, individu berkompetisi agar menjadi yang terbaik (Papalia et al., 2011). Ketika individu berusaha untuk menjadi yang terbaik atau menghindari kegagalan, maka individu memiliki tujuan untuk mencapai kesempurnaan yang kemudian menimbulkan perfeksionisme (Sunkarapalli \& Agarwal, 2017).

\section{Kesimpulan}

Penelitian ini bertujuan untuk mengetahui tingkat perfeksionisme pada penari di Aceh. Hasil penelitian menunjukkan bahwa penari di Aceh memiliki tingkat perfeksionisme tinggi, terutama pada selfevaluative perfectionism yaitu perfeksionisme yang mengevaluasi diri secara negatif. Berdasarkan analisis data sosiodemografi partisipan penelitian, ditemukan bahwa pada penari tradisional, penari perempuan, dan penari berusia dewasa awal memiliki tingkat perfeksionisme tinggi, dibandingkan dengan kriteria demografi lainnya.

\section{Saran}

Kepada partisipan penelitian yaitu para penari, dalam mencapai tujuan hendaknya menyesuaikan dengan standar-standar yang memungkinkan untuk dicapai, dan melakukan evaluasi yang bersifat positif 
terhadap diri sendiri maupun rekan tim. Para penari juga sebaiknya mencoba menceritakan setiap kendala ataupun permasalahan yang dialami yang dapat dilakukan bersama pelatih, rekan tim, maupun bantuan tenaga profesional seperti layanan konseling agar diarahkan untuk menemukan solusi terbaik.

Peneliti selanjutnya yang ingin melakukan penelitian dengan variabel yang sama, dapat mengaplikasikan metode kuantitatif dengan uji komparasi maupun uji korelasi. Peneliti selanjutnya juga dapat meninjau variabel-variabel lain yang berhubungan dengan perfeksionisme seperti kecemasan, konsep diri, self-esteem, eating disorder, maupun prokrastinasi. Selain itu, peneliti selanjutnya juga dapat mempertimbangkan partisipan penelitian selain penari, seperti atlet, mahasiswa, maupun penampil seni lainnya seperti penyanyi, dan pemusik.

\section{Ucapan Terima Kasih}

Peneliti mengucapkan terima kasih kepada Ibu Maya Khairani, S.Psi., M.Psi., Psikolog, Ibu Zaujatul Amna, S.Psi., M.Sc., Ibu Afriani, S.Psi., M.Sc, dan seluruh sanggar tari di Provinsi Aceh.

\section{Kepustakaan}

Agustina, R. (2018). Makna tari ranup lampuan (dengan pemberian uang di dalamnya) bagi masyarakat Banda Aceh (Tesis tidak dipublikasikan). Institut Seni Indonesia, Yogyakarta.

Bläsing, B., \& Schack, T. (2012). Mental representation of spatial movement parameters in dance. Spatial Cognition E Computation, 12(2-3), 111-132. doi:
10.1080/13875868.2011.626095

Burns, D. (1980). The perfectionist's script for self-defeat. Psychology Today, November, 34-51.

Chan, D. W. (2010). Healthy and unhealthy perfectionists among academically gifted Chinese students in Hong Kong: Do different classification schemes make a difference? Roeper Review, 32(2), 88-97. doi: $\underline{10.1080 / 02783191003587876}$

Chua, J. (2014). Dance talent development across the lifespan: A review of current research. Research in Dance Education, 15(1), 23-53. doi: $\underline{10.1080 / 14647893.2013 .825749}$

Conroy, D. E., Poczwardowski, A., \& Henschen, K. P. (2001). Evaluative criteria and consequences associated with failure and success for elite athletes and performing artists. Journal of Applied Sport Psychology, 13(3), 300-322. doi: $\underline{10.1080 / 104132001753144428}$

Eusanio, J., Thomson, P., Psy, D., Jaque, S. V., \& Ph, D. (2014). Perfectionism, shame, and self-concept in dancers. Journal of Dance Medicine \& Science, 18(3), 106-114. doi: 10.12678/1089313X.18.3.106

Frost, R. O., Marten, P., Lahart, C., \& Rosenblate, R. (1990). The dimensions of perfectionism. Cognitive Therapy and Research, 14(5), 449-468. doi: $\underline{10.1007 / \mathrm{BF} 01172967}$

Gittens, C. Y. (2012). A comparative study: Perfectionism in elite ballet dancers and artistic gymnasts (Tesis tidak dipublikasikan). Birmingham: University of Birmingham.

Goodwin, H., Arcelus, J., Geach, N., \& 
Meyer, C. (2014). Perfectionism and eating psychopathology among dancers: The role of high standards and self-criticism. European Eating Disorders Review, 22(5), 346-351. doi: 10.1002/erv.2282

Hewitt, P. L., \& Flett, G. L. (1991). Perfectionism in the self and social contexts: Conceptualization, assessment, and association with psychopathology. Journal of Personality and Social Psychology, 60(3), 456-470. doi: $\underline{10.1037 / 0022-3514.60 .3 .456}$

Hill, R. W., Huelsman, T. J., Furr, R. M., Kibler, J., Vicente, B. B., \& Kennedy, C. (2004). A New measure of perfectionism: The perfectionism inventory. Journal of Personality Assessment, 82(1), 80-91. doi: 10.1207/s15327752jpa8201 13

Jackson, J. (2005). My dance and the ideal body: Looking at ballet practice from the inside out. Research in Dance Education, 6(1-2), 25-40. doi: $\underline{10.1080 / 14617890500373089}$

Koutedakis, Y., \& Jamurtas, A. (2004). The dancer as a performing athlete: Physiological considerations. Sports Medicine, 34(10), 651-661. doi: 10.2165/00007256-200434100-00003

Krasnow, D., Mainwaring, L., \& Kerr, G. (1999). Injury, stress, and perfectionism in young dancers and gymnasts. Journal of Dance Medicine $\mathcal{E}$ Science, 3(2), 51-58.

Morris, G. (2003). Problems with Ballet: Steps, style and training. Research in Dance Education, 4(1), 17-30. doi: $\underline{10.1080 / 14647890308308}$

Nordin-Bates, S. M. (2020). Striving for perfection or for creativity: A dancer's dilemma? Journal of Dance Education, 20(1), 23-34. doi: $\underline{10.1080 / 15290824.2018 .1546050}$

Nordin-Bates, S. M., Cumming, J., Aways, D., \& Sharp, L. (2011). Imagining yourself dancing to perfection? Correlates of perfectionism among ballet and contemporary dancers. Journal of Clinical Sport Psychology, 5(1), 58-76. doi: 10.1123/jcsp.5.1.58

Pallant, J. (2011). SPSS survival manual: $A$ step by step guide to data analysis using SPSS (Edisi keempat). Open University Press.

Papalia, D. E., Old, S. W., \& Feldman, R. D. (2011). Human development (Psikologi perkembangan) (A. K. Anwar, Terj.). Kencana.

Rasminsky, A. (2009). Perfectionism 101 Dance spirit. Diakses melalui https://www.dancespirit.com/perfecti onism 101-2326036484.html

Restela, R., \& Narawati, T. (2017). Tari Rampoe sebagai cerminan karakteristik masyarakat Aceh. Panggung, 27(2), 187-200. doi: 10.26742/panggung.v27i2.260

Schuler, P. A. (2000). Perfectionism and gifted adolescents. Journal of Secondary Gifted Education, 11(4), 183-196. doi: 10.4219/jsge-2000-629

Setyantoro, A. S. (2014). Mengenal Didong Gayo - Balai pelestarian nilai budaya Aceh. Diakses melalui https://kebudayaan.kemdikbud.go.id/ bpnbaceh/mengenal-didong-gayo/

Stoeber, J., \& Otto, K. (2006). Positive conceptions of perfectionism: Approaches, evidence, challenges. Personality and Social Psychology Review, 10(4), 295-319. doi: 


\section{$\underline{10.1207 / s 15327957 p s p r 1004 \_2}$}

Stoeber, J., \& Stoeber, F. S. (2009). Domains of perfectionism: Prevalence and relationships with perfectionism, gender, age, and satisfaction with life. Personality and Individual Differences, 46(4), 530-535. doi: 10.1016/j.paid.2008.12.006

Sunkarapalli, G., \& Agarwal, T. (2017). Fear of failure and perfectionism in young adults. The International Journal of Indian Psychology, 4(3), 92-106.

Thomas, J. J., Keel, P. K., \& Heatherton, T. F. (2005). Disordered eating attitudes and behaviors in ballet students:
Examination of environmental and individual risk factors. International Journal of Eating Disorders, 38(3), 263268. doi: 10.1002/eat.20185

Yatabe, K., Yui, N., Kasuya, S., Fujiya, H.,... \& Musha, H. (2014). Anxiety and mood among ballet dancers: A pilot study on effects of a medical approach involving periodic intervention. Annals of Sports Medicine and Research, 1:1002(1), 1-8. 